\title{
The Use of Dictogloss in Teaching Listening Comprehension for EFL Learners
}

\author{
Maman Asrobi, Khaerul Amni \\ Hamzanwadi University \\ mmnasrobi@gmail.com, amnydaygun@gmail.com
}

\begin{abstract}
The objective of this study was to know the effectiveness of dictogloss in teaching listening comprehension. The design of this research was a preexperimental research design. To collect the data, a pre-test and a post-test was given to the tenth graders of MA Muallimat NW Pancor (30 students). In order to examine the effectiveness of dictogloss, the collected data were submitted to a paired samples t-test by using SPSS 17 for windows. Based on the result of study, the mean score of pre-test (11.10) was lower than post test (13.57). After submitting the data to a paired samples t-test, the present researcher found that there was a significant difference in the mean scores between the pre-test and the post-test, $t_{(\mathrm{df}=29)}=16.49$ at $p<.01$, meaning that the null hypothesis was rejected and alternative hypothesis was accepted. Dictogloss was significantly effective in teaching listening comprehension for the tenth graders of MA Muallimat NW Pancor in the school year 2015-2016. Considering the process and the results of this research, the present researcher suggested that the English teacher use dictogloss as the technique to teach the students.
\end{abstract}

Key Words: Dictogloss, Listening Comprehension

\section{Introduction}

English is one of the language that most important in the world because that is the international language. English language used by many people in social life such as in the economic life, tourism, technology, and politics. It is also usually used when two or more people from different country are involved in communication like instance in international workshop, seminar, meeting, 
conference, etc. So that way the teaching of English is applied from primary school up to university level as one of compulsory subject.

Regarding the language learning, English is one of the subjects stated in the school curriculum that has to be taught. Knowledge of English is assumed to be an investment for a better career, better pays, and more advanced knowledge toward achievement in personal life, therefore language learning absolutely needed by people in the world.

In learning English, there are four skills that should be mastered by the students, those are listening, speaking, reading, and writing. The objective of English lesson in senior high school is the students able to develope communication ability orally and in a written.

To master speaking and writing, listening comes as the bridge of the productive skills because listening is the activity to get information which is has an important role to understand foreign language and as an input to learn speaking. Listening is the most frequently used language skill in everyday life. Reseacher (Rivers \& Morely, 2008; Wulandari, 2011, p. 15) propose that" we listen twice as much as we speak, four time as much as we read, and five times as much as we write. So listening is the most important to learn English."

Listening also includes comprehension of meaning bearing-words, phrases, clues, sentences, and connected discourse. Furthermore, Wift (2000 cited in Osada, 2004, p. 21) states that "listening is an invisible mental process, making it difficult to be described". Listeners must discriminate between sounds, understand vocabulary, grammatical structure, interpret stress and intentions, retain and interpret this within immediate as well as the larger socia-cultural context of the utterance.

However there were some problems that faced by the students related to listening comprehension. Base on the researcher observation of the students and the teachers at MA Muallimat NW Pancor, the problems faced by the students such as: the stsudents find difficulty to know the meaning of the words and phrases, difficult to identify the communicative purpose of the listening text, difficult to finding main idea, and difficult to finding spesific information of the listening text. Thuse, many students said that listening is a difficult lesson.

Thuse problems above could not only be addressed to the students' personal factor but also addressed to the teacher's factors in teaching listening comprehension as the result, the students rarely to listen more, lazy to exsercise about listening comprehension not interested to study about English especially listening. And then from the techer's factor, the teacher not apply a good method 
or technique so the students feel bored and not interested to study English especially listening. It made the students difficult to understand.

To solve that problems the teachers should search a way out to overcome the condition by applying some techniques and strategies to enhance the students' ability in listening. Therefore, the teacher should apply a method, a strategy or a technique which can encourage the students to be more active in the teaching and learning process. Base on the Department of National Education stating" Teachers can give a modal to teach something or to learn something" (translated version) (Direktorat Jendral Pendidikan Dasar dan Menengah, 2002). The teachers should also create a good learning atmosphere so that the students can take part actively in the classroom activities.

There were many techniques that had been developed in the teaching of listening comprehension. One of them was dictogloss that could be developed by the teacher in the classroom. Dictogloss is a strategy developed by Ruth Wajnryb (1990 cited in Herrel \& Jordan 2004, p. 242) used to the high school students, but it can be adapted for use with the all ages. It is especially effective with english language learners because the strategy focuses on fluent academic language and supports learners in listening and recalling good English language models (Gibbons, 1993 cited in Herrel \& Jordan 2004)

In dictogloss, a short text was read at normal speed to a class of learners who jot down familiar words as they listen. At the end of dictation stage, most learners have only a small number of isolated words (or fragments) which together make up a very inchohesive "battered text". In small groups, the students then pool their resources to construct their versions that the students produce subjected to close analysis and comparison. Through both the tasks of reconstruction and following error analysis, students refine their understanding of the language they have used.

The dictogloss technique had many benefit for the students. This listening activity could built students' motivation to study by "coopetisi" (cooperative and competition) activity. The students can be trained to worked together in a group, so that their sense of togetherness is built, and they could comfortable to do their activity. In the while and post activity, students worked individually. It built selfconfidence and responsibility.

Beside that, the topical warm-up in the preparation stage helped the students to found the main idea and specific purposes of the text. And then, the vocabulary preparation in the preparation stage could helped the students to find the words meaning. Meanwhile, in the reconstruction the students were asked to reconstructed the listening text in writing. This activity could helped the students 
to maintain the informational content of the listening text. So that the students could found the specific information of the listening text.

By considering the benefit of dictogloss, the researcher would like to implement it in teaching listening in the hope of improving the students' listening comprehension of the tenth graders of MA Muallimat NW Pancor in the school year 2015-2016.

This research is hopefully useful to help the teacher and the students in teaching and learning process, theoretically and practically.

1. Theoretically

The result of this study may provide many new insights in studying listening skill especially about teaching listening comprehension using dictogloss.

2. Practically

a) For the teachers

This study was expected to be worthwhile for the English teachers in enhancing their strategies in teaching and learning process.

b) For the students

Using dictogloss, the students will be facilitated to listen well so that listening comprehension are not difficult anymore to do it and easier to understand.

c) For further researchers The result of the study was expected to helped the next researchers to find out an interesting medium in teaching listening and become references for the next researcher.

\section{Method}

This study was quantitative approach. The present researcher used pre experimental design by using one group pre test, post test. In this case, the present researcher analyzed the students' listening comprehension.

\subsection{Participants}

the population of this study was 291 students consist of ten classes (XAgama 1, X-Agama 2, X- IPA 1, X-IPA 2, X- IPA 3, X- IPA 4, X- IPA 5, XIPA $6, X$ - IPS 1,X- IPS 2). Because of the population was big enough to investigated, the present researcher took a sample by cluster random sampling. The present researcher took and randomized the ten classes by lottery and the class that choosen was X IPA 6.

\subsection{Procedure}

2.2.1. Preparation for assessment 
First,to to active the students' background knowledge, the teacher tells the students the topic that will they listen and then the students ask the teacher some vocabularies related to the topic that was given. Second, the students do listening process. because the students know the topic and difficult vocabulary, so they will eazy do the listening process. learners may need to hear the recording several times. The first time, the students are not permitted to take notes or write anything. They only listen to get a general idea about the text. The second time they can take notes. As inexperienced learners tend to try to write down everything, teachers should emphasize that they should focus on key words only that will help them with the reconstruction of the text. Third, reconstruction, Reconstruction is the central part of the dictogloss listening lesson. Working in small groups (3-4 people), students discuss what they heard and attempt to produce a coherent text close in content and organization to the original version. Limiting the group size is important to allow for individual contributions to be incorporated into the group effort (Wajnryb, 1990 cited in Grenfell \& Harris, 2002). The last is analysis and correction, In a dictogloss listening class, the main purpose of the analysis and correction stage is to identify the problems students had wit text comprehension. Therefore, although the reconstruction task requires writing ability, spelling mistakes should be less of a concern. One well-recognised characteristic of language processing is that learners tend to remember the content of the message rather than the exact words used. The reconstruction task asks students to use their language ability to put words in the meaningful units. The assessment has ten components for evaluation: (1) finding meaning of the words and phrases (2) finding main idea (3) finding specific information (4) identifying communicative purpose of the text.

\subsubsection{Data collection}

\section{Identification of Variables}

Based on the title of this research, it was clear enough that there was one variable which was be investigated in this research namely: dependent variable. The dependent variable was listening comprehension.

2. Definition of the variable

Listening is considered as the basic skill for language acquisision. It is proved by the fact that a new born baby starts acquire a language by listening to the voices around his or her environment before he or she starts to speak and learn to read and write. Listening is the important lesson to begin study English because that is the first thing that the students should to do before study speaking, reading, and writing to increase their knowledge and to get more informations. Underwood (1989) puts forward a simple definition that listening is " the activity of paying 
attention to and trying to get meaning from something we hear." Furthermore, according to International Listening Assosiation (ILA) (1995, p. 6), listening is the active process of receiving, constracting meaning from, and responding to spoken and/or non-verbal message.

So from the statement that stated by some expert above, it can be concluded that listening is very important because the students have to excercise listen more than speak, read, and write. Listening is the first thing that have to do. Listening is the series of activity that should be done in teaching learning process to gathering more information. The students should be able to receive the information from the speaker, able to construct, and able to responding to spoken and non verbal message.

3. Instrument

In a study or research, the definition of instrument and method was different. According to Suharsimi (2010, p. 160)" research method is the way that is used in collecting data, while instrument is a tool that is used in collecting data. The instrument is questions or exercises or other tools which are used to measure skill, knowledge, intelligence, achievement, and attitude of someone or a group of people."

An instrument was absolutely important at finding out the result of research, so the instrument must be well prepared. The instrument used in this study was test. In line with that explanation, the instrument which used in this research was listening test. The form of test was multiple choice.

In this study the researcher took theinstrument items from National examinition, so the instrument not neccessary validity or reliability test because the National examinition had National standard.

4. Method of Data Collection

In collecting data the present researcher lists some steps, those were:

a) Pre-test

It was the first method of data gathering that was used by the researcher. The researcher gave pre test to the experiment group as the sample of research. Pre test aimed at knowing the students' listening comprehension done before having treatment. The test held by the researcher.

b) Treatment

In the process of treatment, the researcher taught the students by using dictogloss in teaching listening comprehension in context to the experimental group. Treatment was given three times for the students.

c) Post test 
In this part after the students were being to treated by dictogloss for experimental group, the researcher delivered a test of post test to all students and asked them to do the test individually on certain given a time. Finally, the students' paper sheet submitted and the students' result treated as the data of the study. The test was similar to the pre test.

\subsubsection{Data analysis}

In this study, the present researcher used spss 17 for windows to calculated the data. The first, the present researcher analyzed the mean score and standard deviation by using descriptive statistics. And then to find out the normal distribution, the present researcher used One-Sample Kolmogorov-Smirnov Z and to find out the homogeneity of variance One -Way Anova was used. To know the significatly effect of dictogloss, the preseant researcher used paired-samples ttest.

\section{Result}

Referring to the data gained in pre-test, the result of students was follows: in the pre-test the lowest and the highest score were 28 and 64, while in the posttest, the lowest and the highest score obtained were 40 and 80 . In addition, the mean score of pre-test was 11.10 while in post-test was 13.57 . The mean scores of post-test was higher than the mean scores of pre-test, it indicated that dictogloss was effective in teaching listening comprehension. And then for the normality testing according to the result of One-Sample K-S, all of the values of Kolmogorov-Smirnov in pre-test and post-test were higher than values of the significance $(p)=.05$. The value of Kolmogorov-Smirnov in pre test was .81 while the value of significance in post test was .58. It implied that the data was normal. Moreover the data was homogenous because Based on the calculation of One-Way ANOVA, the value of $p=.28$ at Levene's test is 1.160 . The value of $p$ $=.28$ that more than .05 , it means that the data was homogeneous. For hypothesis testing, the present researcher found that there was a significant difference in the mean scores between the pre-test and the post-test, $t_{(\mathrm{df}=29)}=16.49$ at $p<.01$, meaning that the null hypothesis was rejected and alternative hypothesis was accepted. It meant that there was significant effect of dictogloss in teaching listening comprehension for the tenth graders of MA Muallimat NW Pancor in the school year 2015-2016.

\section{Discussion}


Dictogloss was significantly effective in teaching listening comprehension because this technique has some benefits. First, this technique is interactive. The students can interact with the teacher and the other friends because the steps in this technique available to do that. For example the first step in this technique is preparation. The teacher prepare the topic and give the students more vocabulary before listening process. From that steps the students can interact with the teacher. And then the students can interact with the others when they are making some groups and working together because this technique has steps called reconstruction. In this step the students make some groups.

Second, they are not bored because they work together with their friends. this step can help the students to listen well because they discuss with their group what they have heard, so they can help each other and combine what they have heard. Usually listening always done by the students by theirselves but this technique give different activity. The students in the classroom not bored because there are some activity in dictogloss that make them excited to study listening comprehension also. That activity is preparation, listening procedure, reconstruction (making group), and analysis and correction.

Third, the students more antusiast to study about listening comprehension because after they work together the teacher and the students directly do analysis and correction, so the students will be more antusiast because they want to compare the result of each group. Usually the students will be more antusiast when they know the result of their work directly, moreover if they are in a group, they can directly compare their result with the other groups. Beside more antusiast, Correction and analysis also help the students more understand about what they have listen and write. When analysis and correction they can repair the grammar and language accuracy in language use with the teacher.

In addition, the finding of this study proved by the theory proposed by Wajnaryb. Wajnryb (1990 cited in Zorana, 2010, p. 41) argues that" dictogloss gives students a more precise understanding of English grammar than do other approaches and consequently leads to higher accuracy in language use." Compared to other more traditional approaches to teaching grammar the value of dictogloss is in its interactive approach to language learning. Text reconstruction promotes both the negotiation of meaning and the negotiation of form. It is a cooperative endeavour which forces learners to stay actively engaged in the learning process.

the finding of this study strenghten the finding of present researcher related to the use of dictogloss in teaching listening comprehension conducted by Riestu Dea Yuniarizki (2011) and Abdul Arif (2013). The finding of their study proved 
that there are significant different after applying technique in teaching listening comprehension especially when the researcher use dictogloss in teaching listening comprehension.

\section{Conclusion}

Referring to the result of research, the present researcher concluded that the students' mean score in post-test was higher than pre-test, meaning that there were a significant difference in the mean scores between the pre-test and the post-test, $t_{(\mathrm{df}=29)}=16.49$ at $p<.01$. It means that the null hypothesis was rejected and alternative hypothesis was accepted. Furthermore, using Dictogloss is significantly effective in teachinglistening comprehension for the tenth graders of MA Muallimat NW Pancor in the school year 2015-2016.

Furthermore, based on the conclusion above, the present researcher offer some suggestions. First, the headmaster should motivate and support the English teacher to choose appropriate technique, method, approach, and strategy in teaching listening comprehension. Second, The English teachers are expected to be able to choose a good approach, method, and strategy, one of them is using dictogloss in teaching listening comprehension. Last, Further researcher should select an appropriate media in conducting further investigation to find the main factors which can influence the students' ability, especially in students' listening comprehension.

\section{References}

Arif, A. (2013). The effectiveness of dictogloss to teach writing skill viewed from students' risk-taking (an experimental study at the English education department of stkip-pgri pontianak in the academic year 2012/2013. Unpublish thesis available online at diligual.uns.ac.id (acced on February $\left.15^{\text {th }} 2016: 14.00\right)$

Herrel A. \& Jordan M. (2004). Fifty strategies for teaching English language learning. California: Pearson Education.

Moedjito. (2014). Basic Statistic For Research In Language Education. Selong: STKIP Hamzanwadi Selong.

Osada, N. (2004). Listening comprehension research:a brief review of the past thirty years. “International Journal”'ISSN 1349-5135,Vol. 3,pp. 53-56.

Sugiyono. (2012). Metode penelitian pendidikan.Bandung:Alfabeta 
Suharsimi. (2010). Prosedur penilaian: Suatu pendekatan praktik. Jakarta: PT Rinaka Cipta

Widodo T. (2009). Metode penelitian kuantitatif. Surakarta:Lpp Uns Dan Uns Press

Wulandari, F. (2011). Improving students' listening ability using spot the dictogloss technique (a classroom action research at eight year students of SMPN 3 Ngargoyoso in academic year of 2010/2011). Available online at digilib.uns.ac.id (accsessed on 17th february 2016: 08.00)

Yuniarizki, D.R. (2011). The role of english songs in improving students' listening skill; an experimental research at the eleventh year students of SMAN 1 narmada in academic year 2010/2011. unpublish Thesis

Zorana. (2010). Dictogloss as an method of teaching listening comprehension to l2 learners. Vol. 3,no.1.Marach 2010 available online at www.ccsenet.org.elt (accessead on 16th february 2016: 16.00) 